\title{
Al-20\%Ag 合金における復元
}

\section{ーアルミニゥム合金における G.P.ゾーンの成長と復元（第 2 報）一}

\author{
広瀬 洋一*・浅野 和彦**・平野 蜸一*** \\ Reversion in aluminum-20\% silver alloy. \\ -Growth and reversion of G.P. zones in aluminum alloys (2nd report)- \\ UDG $669.715^{\prime} 22: 621.785 .6 .7$ \\ HIROSE Yoichi*, ASANO Kazuhiko** and HIRANO Kenichi***
}

The mechanism of reversion in $\mathrm{Al}-20 \% \mathrm{Ag}$ alloy aged at $70^{\circ}$ or $130^{\circ} \mathrm{C}$ for different periods was investigated by measurements of electric resistivity and proof stress.

The resistivity of aged alloys was increased to the maximum, and then, decreased. While, the proof stress was only linearly decreased. The degree of reversion was satisfactorily explained in terms of the metastable miscibility gap given by Baur and Gerold.

The diffusion processes during the reversion was analyzed in reference to the metastable miscibility gap. It was shown that the reversion was due to the transition from $\eta$ into $\varepsilon$ zone, not due to the solution of G.P. zones. The activation energy of the diffusion of Ag during the reversion was determined to be $29.0 \mathrm{kcal} / \mathrm{mol}$ by considering changes in the matrix concentration and the zone size depending upon the reversion temperature according to the metastable miscibility gap. The value was in remarkable agreement with the activation energy of diffusion of $\mathrm{Ag}$ in $\mathrm{Al}$ and $\mathrm{Al}-\mathrm{Ag}$ alloy, or 29.0 and $28.9 \mathrm{kcal} / \mathrm{mol}$, respectively. Therefore, it was concluded that the rate controlling step in the reversion of $\mathrm{Al}-20 \% \mathrm{Ag}$ alloy was the diffusion of $\mathrm{Ag}$ in $\mathrm{Al}-\mathrm{Ag}$ solid solution.

(Received Sept. 14, 1970)

\section{1. はじめに}

前報1) において, $\mathrm{Al}-\mathrm{Ag}$ 合金におけるG.P.ゾーンの生 成および成長が Baur と Gerold ${ }^{2)} か ゙$ 提唱した準安定状態 図に従がうことを報告し，この合金においてはをおよび クの二種類のG.P.ゾーンが存在することを確認した。そ の際, 低濃度領域における $\varepsilon-\eta$ 遷移温度 $T_{\varepsilon-\eta}$ が Baur らの予想よりも著しく高いことが示された。Al-Ag 合金 におけるG.P.ゾーンの復元が準安定状態図によつて支配 されるかどうかはまだわかつていない。本研究では種々 の時効条件下で成長せしめたG.P.ゾーンの復元挙動を調 べその機構を準安定状態図と関連ゔけたが，合金組成に よつてそれが顕著に異なることを見出した。本報は $\mathrm{Al}-$ $20 \% \mathrm{Ag}$ 合金の復元機構についてまず報告する。
低温時効硬化した $\mathrm{Al}-\mathrm{Ag}$ 合金の硬度が二相領域の高温 にもちきたされた場合にほとんど完全に焼入れ時のレベ ルまで低下することは以前から知られている ${ }^{3)} \mathrm{Al}-\mathrm{Cu}$ 合金の場合にはこれがG.P.ゾーンの固溶消滅によること がX線的に確められている。しかし，Guinier`によれば $\mathrm{Al}-\mathrm{Ag}$ 合金では復元に伴つてG.P.ゾーンは消滅せず，む しろ成長する。後に Gerold とその共同研究者 ${ }^{5 ~ 6)}$ はX線 小角散乱, 電気抵抗および硬度測定の結果に基づいて $\mathrm{Al}-\mathrm{Ag}$ 合金の復元が，規則的原子配列をもつクから不規 則配列の Hirano 》) は広い組成範用の $\mathrm{Al}-\mathrm{Ag}$ 合金の熱力学的測定と 計算とから, $\mathrm{Al}-\mathrm{Ag}$ 合金においてをは時効硬化に関与せ ず, 復元が $ー ク$ の変態であることを確認した。

一方，Beton と Rollason ${ }^{8)}$ は $\mathrm{Al}-7.93 \sim 36.7 \% \mathrm{Ag}$ 合金

* 昭和電工株式会社 (埼玉県秩父郡) Showa Denko K.K. (Chichibu Saitama)

** 株式会社神戸製鋼所中央研究所（神戸市）Central Research Laboratories, Kobe Steel Ltd. (Kobe)

*** 東北大学工学部 (仙台市) Department of Materials Science, Faculty of Engineering, Tohoku Univ. (Sendai) 
を, $125^{\circ} \mathrm{C}$ にて 66 時間時効後, 種々の温度で復元処理し た後の, 復元量対温度の関係に 2 つの不連続点が現われ ることを示し，低温および高温における不連続がそれぞ れG.P.ゾーンおよ.び積層欠宿の消滅によると考えた。こ れに対して Kelly と Nicholson' ${ }^{9)}$ は Beton らが指摘して いる温度領域では積層欠宿は存在しないといら電顕観察 の結果をもつてこれに反論した。

運動論的な面からG.P.ゾーンの復元機構を明らかにし ようとした研究はまだなされていない。Ohta ${ }^{10)}$ はAl-20 $\% \mathrm{Ag}$ 合金における G.P.ゾーンの復元に伴つて大きな電 気抵抗変化を観察した。Borchers と Thym ${ }^{11)}$ 同様な変化 を認めた。Borchers らはさらに Al-Ag および $\mathrm{Al}-\mathrm{Ag}-\mathrm{Cu}$ 合金におけるG.P.ゾーンの復元の運動論が時効温度によ つて異なることを示した。たとえば $\mathrm{Al}-20 \% \mathrm{Ag}$ 合金の復 元のための活性化エネルギが， $100^{\circ} \mathrm{C}$ で時効した後では $1 \mathrm{eV}$ ，室温で時効した後では $0.6 \mathrm{eV}$ であることが示さ れている。これらの研究者はG.P.ジーンの復元の機構に ついてはとくに言及していない。

以上のように $\mathrm{Al}-\mathrm{Ag}$ 合金における復元が G.P. ゾーン の消滅によるのかあるいは変態によるのか明らかでな い。本研究は復元を運動論的に調べてその機構をさらに 一層明らかにする目的で行なつたものである。

\section{2. 実験方法}

$\mathrm{Al}-20 \% \mathrm{Ag}$ 合金は高純度素材より溶製した。化学分析 の結果, $\mathrm{Ag}$ 含量は $19.5 \%$ であつた。試料の作製および 引張試験ならびに電気抵抗測定の方法は前報1)のとおり である。

合金試料は $540^{\circ} \mathrm{C}$ にて 1 時間溶体化処理後, $0{ }^{\circ} \mathrm{C}$ の水 に焼入れた。試料はすべて焼入れ後, 10 秒以内に液体窒 素に浸漬した。なお, 各時効処理ごとに復元実験に必要 な試料全体を同時に焼入れ，時効して熱処理のバラツキ を極力防止した。時効および復元のための熱処理はシリ コン油浴（70 160年） または硝酸塩浴（170〜240 ${ }^{\circ} \mathrm{C} ）$ 中にて行ない，浴はすべて激しくかくはんした。

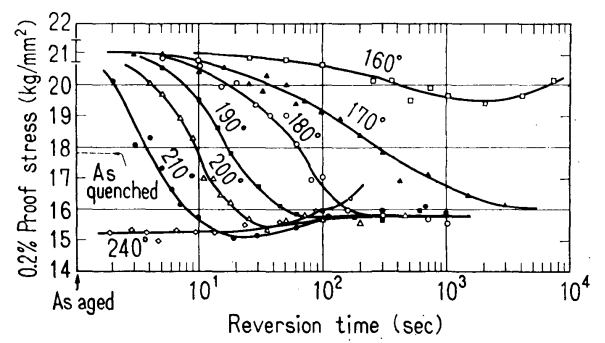

Fig. 1 Strength-reversion curves of $\mathrm{Al}-20 \% \mathrm{Ag}$ alloy aged at $130^{\circ} \mathrm{C}$ for 2 days, reversion temperature is indicated in the figure.

\section{3. 実験結果}

\section{1 引張試験}

$130^{\circ} \mathrm{C}$ にて 2 日間時効した $\mathrm{Al}-20 \% \mathrm{Ag}$ 合金を $160 \sim 240$ ${ }^{\circ} \mathrm{C}$ 各温度で復元処理した場合の $0.2 \%$ 耐力の変化を Fig. 1 に示す。いずれの場合も耐力ははじめ減少し, 極 小を経て再び上昇する。耐力の最大低下量は復元温度が 高いほど大きいが，最低耐力值に達するまでの時間 $\mathrm{t}_{m}$ は 逆に短かくなる。 $170^{\circ} \mathrm{C}$ 以上の復元では耐力は焼入れ直

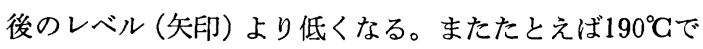
の復元の場合, 耐力值は $15.8 \mathrm{~kg} / \mathrm{mm}^{2}$ まで低下した後増 加するがこれは前報1) で示したように，焼入れ後直ちに $190^{\circ} \mathrm{C}$ で時効した場合と全く同様である。

Fig. 2 は復元による最大耐力変化量, $\Delta \sigma_{\max }$, と復元 温度, $T_{R}$, との関係を示す。 $T_{R}=170^{\circ} \mathrm{C}$ を境として $\Delta \sigma_{\max }$ が急激に増大している。 $T_{R} \geqq 170^{\circ} \mathrm{G}$ では耐力変化 量は $T_{R}$ によらずほほ一定值を保つ。Betonら ${ }^{8}$ によれば, $\mathrm{Al}-20 \% \mathrm{Ag}$ を $125^{\circ} \mathrm{C}$ で 66 時間時効した後の復元に伴う最 大硬度変化， $\Delta H_{\max }$ は Fig. 2 に示すような $T_{R}$ 依存性 をもつ。Beton らは $170^{\circ} \mathrm{C}$ と $220^{\circ} \mathrm{G}$ に不連続があるとして この曲線を解釈したが耐力変化には明瞭な不連続は認め られない。Beton らの解釈はかなり，人為的であるよう に思われる。第 1 に, $220^{\circ} \mathrm{C}$ 前後における $\Delta H_{\max }$ の差は $2 \sim 3$ であるが，実際の硬度のバラッキは 5 程度みこま れることが普通であつて，とくに不連続とみなす必要は ない。第 2 にBeton ら自身の測定結果によればこの不連 続は7.93，29.2および36.7\% Agを含む合金では認められ ていない。それゆえ， $\Delta H_{\max }$ の変化は $\Delta \sigma_{\max }$ と同様に $T_{R}$ とともにはじめ増大してある温度以上で飽和すると 解釈すべきであると考えられる。このような挙動は $\mathrm{Al}-$ $\mathrm{Cu}$ 合金においても認められた ${ }^{122}$ 。

\section{2 電気抵抗測定}

\subsection{1 $130^{\circ} \mathrm{C}$ で時効した試料の復元}

耐力変化の場合と同様, $130^{\circ} \mathrm{C}$ にて 2 日間時効した $\mathrm{Al}-$ $20 \% \mathrm{Ag}$ 合金を $170 \sim 220^{\circ} \mathrm{C}$ の各温度で復元処理した場合

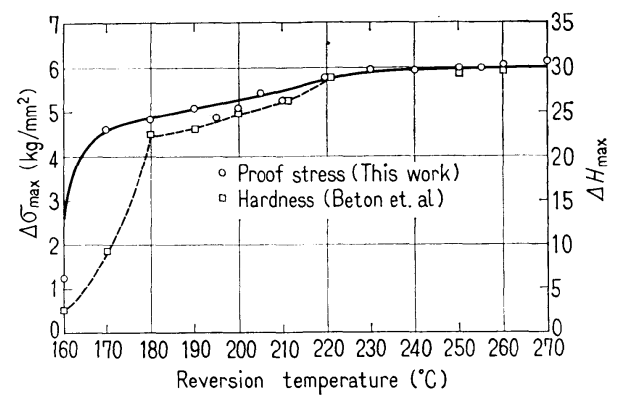

Fig. 2 Maximum strength decrement vs reversion temperature relation of $\mathrm{Al}-20 \% \mathrm{Ag}$ alloy aged at $130^{\circ} \mathrm{C}$ for 2 days. 
の電気抵抗変化を Fig. 3 亿示す。縦軸は時効直後の值 $R_{o}$ に対する変化量 $\Delta R_{t}$ の百分率で示してある。いずれ の温度に㧊いても電気抵抗は著しく増加し, 極大を経た 後減少する。復元による最大電気抵抗增加量, $\Delta R_{\max }$ は $T_{R}$ が高いほど大きく, 反対に電気抵抗極大に達するま での時間， $t_{m}$ は短かくなる。 $t_{m}$ は耐力がほぼ最低值に なるまでの時間に等しい。

なお，焼入れ直後の電気抵抗值は Fig. 3 のスケール では 96 であり， $220^{\circ} \mathrm{C}$ の復元処理においてもその半分程 度しか電気抵抗は変化しない。

電気抵抗復元曲線の形状は時効条件によつてじやつか ん異なる。Fig. 4 は $130^{\circ} \mathrm{C}$ にて $1 \sim 864$ 時間時効した $\mathrm{Al}-$ $20 \% \mathrm{Ag}$ 合金の $190^{\circ} \mathrm{C}$ に打ける電気抵抗復元曲線を比較 したものである。時効時間が長くなるにつれて電気抵抗 の極大值は小さくなり, それに達するまでの時間は長く なる。8 864 時間時効した合金の復元曲線は他のものとじ やつかん異なつているが，これは前報に示したように， この時効段階ですでに $\gamma^{\prime}$ 相が析出していることによる と考えられる。また時効時間が長くなるにつれて, 電気 抵抗のピークは緩慢になり，480および864時間時効した 合金の場合は電気抵抗は最大值に達した後, ほぼ一定値 を保ち， $\gamma^{\prime}$ 相の析出によると考えられる急激な減少に対 する潜伏期に相当する部分が現われる。

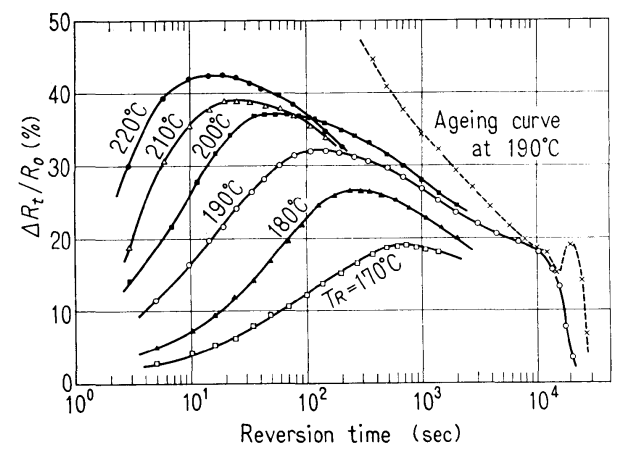

Fig. 3 Resistivity-reversion curves of $\mathrm{Al}-20 \% \mathrm{Ag}$ alloy aged at $130^{\circ} \mathrm{C}$ for 2 days.

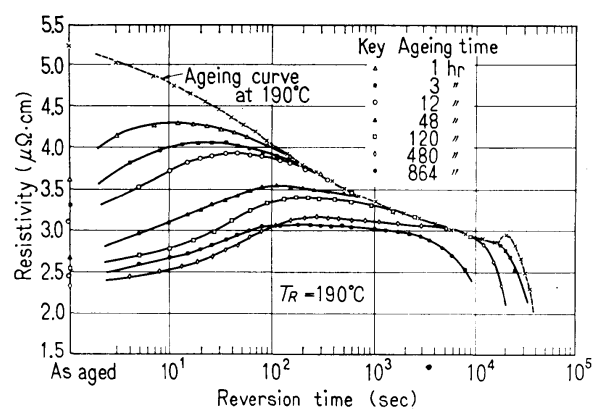

Fig. 4 Effects of ageing time at $130^{\circ} \mathrm{C}$ on resistivity-reversion curves at $190^{\circ} \mathrm{C}$.

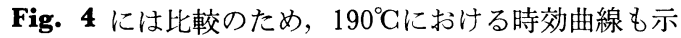
してある。時効の早い段階（120 時間以前）では電気抵 抗は極大を経た後, 漸近的に時効曲線に近づき，最終的 には一致する。しかし復元曲線においては $\gamma^{\prime}$ 相析出の ための急激な抵抗減少に先立つ小さな極大は認められな $\checkmark$ 。

\subsection{2 $70^{\circ} \mathrm{C}$ で時効した試料の復元}

Fig. 5 および Fig. 6 は70Cにてそれぞれ22日および 120 日間時効した $\mathrm{Al}-20 \% \mathrm{Ag}$ 合金の電気抵抗復元 曲 線 を示す。復元曲線の形状, 最大復元量と抵抗最大までの 時間の復元温度依存性等は $130^{\circ} \mathrm{C}$ で時効した試料のもの とほぼ同様であつた。ただし後に示すように，電気抵抗 極大に達するまでの時間 $t_{m}$ は時効時間が長いほど長 い。

一方, $70^{\circ} \mathrm{C}$ にて 168〜2880時間時効した後, $190^{\circ} \mathrm{C}$ で復 元処理した場合の電気抵抗変化は Fig. 7 に示したよう に，時効時間によつて， $130^{\circ} \mathrm{C}$ で時効した場合ほど大き な変化はない。またいずれの場合も復元後期では復元曲 線はその温度での時効曲線にほぼ一致する。

\section{2 .3 電気抵抗の極大について}

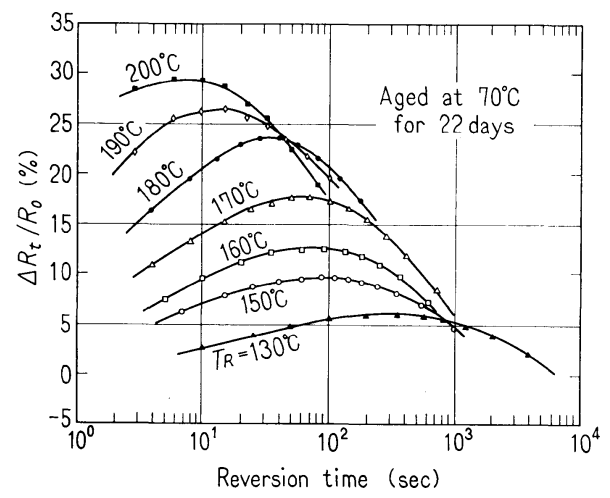

Fig. 5 Resistivity-reversion curves of $\mathrm{Al}-20 \% \mathrm{Ag}$ alloy aged at $70^{\circ} \mathrm{C}$ for 22 days.

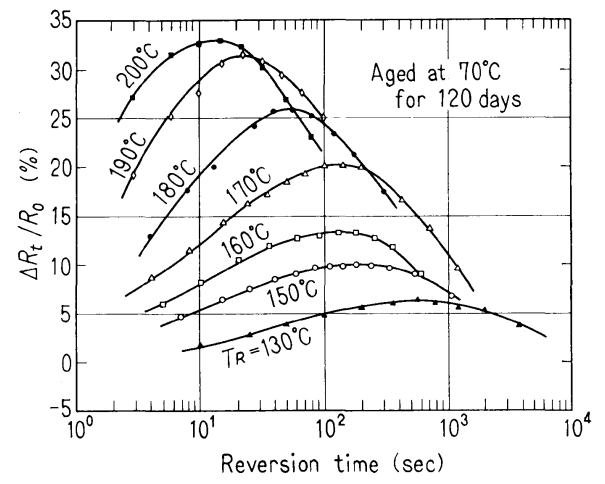

Fig. 6 Resistivity-reversion curves of $\mathrm{Al}-20 \% \mathrm{Ag}$ alloy aged at $70^{\circ} \mathrm{C}$ for 120 days. 
すでに示したように，復元に伴い電気抵抗ははじめ増 加し，極大を経て減少する。ここで最大抵抗増加量, $\Delta R_{\max }$ について考える。Fig. 8 は $130^{\circ} \mathrm{C}$ まは $70^{\circ} \mathrm{C} て ゙$ 時 効した $\mathrm{Al}-20 \% \mathrm{Ag}$ 合金における $\Delta R_{\max }$ と復元温度 $T_{R}$ の関係を示す。 $\Delta R_{\max }$ は $T_{R}$ とともに増大するが $70^{\circ} \mathrm{C}$ で 時効した合金の場合にみられるように，160～170 Cににお ける増加が著しい。これは復元による耐力変化の傾向と よく一致する (Fig. 2)。また $\Delta R_{\max }$ は $T_{R}$ が一定であれ ば時効温度および時効時間によらず， $T_{R}$ によつて決ま ることがわかる。これらのことは $\mathrm{Al}-20 \% \mathrm{Ag}$ 合金の復 元が Baur と Gerold ${ }^{2)}$ の準安定状態図に支配されること を強く示唆している。

一方， $t_{m}$ は時効時間に依存する。Fig. 9 は $\Delta R_{\max }$ と $t_{m}$ を $130^{\circ} \mathrm{C}$ における時効時間に対してプロットしたもので ある。 $\Delta R_{\max }$ ははじめ増加するが後飽和してほぼ一定值 をとるが, $t_{m}$ の対数は時効時間の対数に比例して増加す る。その傾きは $130^{\circ} \mathrm{C}$ 時効に执いては $0.57,70^{\circ} \mathrm{C}$ 時効に おいては0.53であつた。

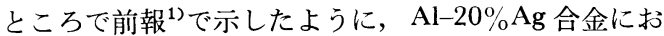
けるG.P.ゾーンは時效初期を除けば次式に従がつて成長 する：

$$
R_{t}{ }^{3}-R_{o}{ }^{3}=\alpha t
$$

ここで $R_{t}$ および $R_{o}$ はそれぞれ時間 $t$ および $t_{o}$ でのゾ ーン半径， $\alpha$ は合金および温度によつて定まる定数であ る。G.P.ゾーンの復元が溶質原子の拡散に律速されると 寸れば，その抬散距離は第一近似ではG.P.ゾーンの半径 に比例する (詳細は後述)。したがつて， $\beta$ を比例定数と して,

$$
\sqrt{2 D t_{m}}=\beta R_{t}
$$

が成立つ。(1)および(2)式から $R_{t}$ を消去すれば次式がえ られる（ただし $R_{o} \approx 0$ と仮定）:

$$
\log t_{m}=\frac{2}{3} \log t+\operatorname{cost}
$$

すなわち $t_{m}$ の対数を時効時間の対数に対してプロット

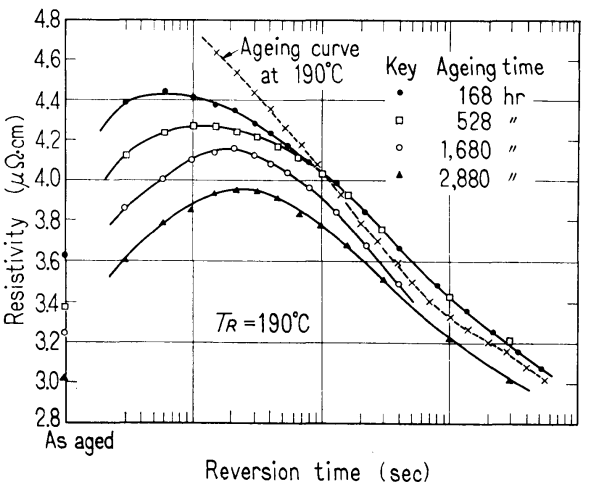

Fig. 7 Effects of ageing time at $70^{\circ} \mathrm{C}$ on resistivityreversion curves at $190^{\circ} \mathrm{C}$.
すれば直線がえられ，その傾きは $2 / 3 に$ 等しい。一方， Baur と Gerold ${ }^{2)}$ は(1)式に対して $R_{t}{ }^{4}$ が時効時間に比例 して増加することを示しているが，この場合には值線の 傾きは $1 / 2$ となる。それゆえ， $\log t_{m}$ と時効時間の対数 との直線の傾きは0.5〜0.7の間にあり, 本実験の結果と 一致している。すなわち，G.P.ゾーンの復元が溶質原子 の拡散に律速され，復元に要する時間がジーンの大きさ によつて決まることがわかる。しかし，実際の復元時の 拡散は $T_{R}$ による母相濃度とそれに伴うゾーン半径の変 化をも考虑せね柿ならない。つぎにこれについて検討す る。

\section{4. 考 察}

G.P. ゾーンの復元が $\varepsilon-\eta$ 変態であつても，ゾーンの 固溶消隇であつても，それに伴つて母相濃度が変化しな ければならないから，それは溶質原子の挔散によつて支

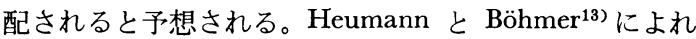
ば $\mathrm{Al}-0 \sim 30 \mathrm{at} \% \mathrm{Ag}$ 合金における $\mathrm{Ag}$ の拡散のための活 性化エネルギは組成によらず一定であり，その值は $28.9 \mathrm{kcal} / \mathrm{mol}$ である。それゆえ，復元のための活性化エ ネルギは，時効後に何らかの理由で過剩な空孔が残存し ていない限り，この值に等しいと考えられる。

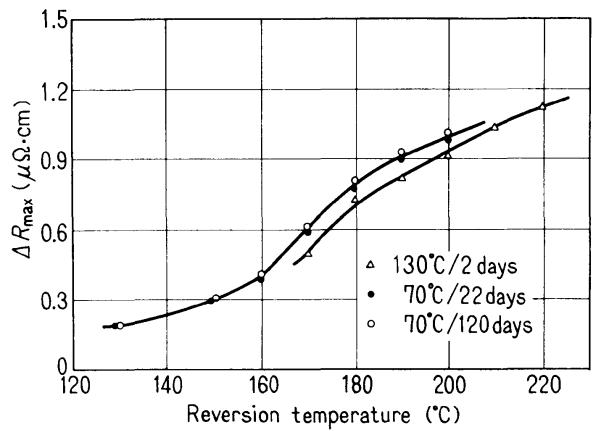

Fig. 8 Maximum resistivity increment vs reversion temperature relation of $\mathrm{Al}-20 \% \mathrm{Ag}$ alloy aged at $130^{\circ}$ or $70^{\circ} \mathrm{C}$.

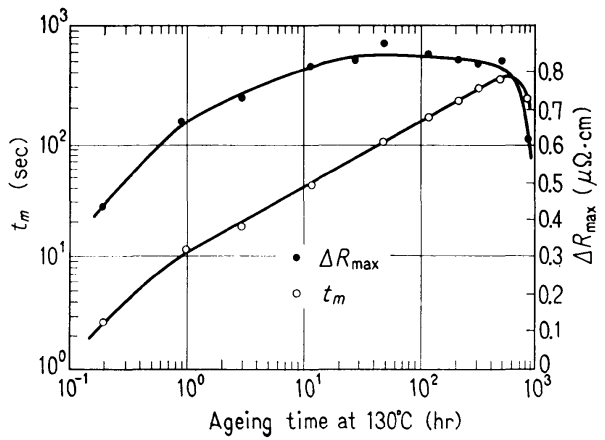

Fig. 9 Relation between reversion time and ageing time at $130^{\circ} \mathrm{C}$. 
Table 1 Data used for calculation of the diffusion coefficients of Ag during reversion.

\begin{tabular}{c|c|c|c|c|c|c|c}
\hline \hline Temp. $\left({ }^{\circ} \mathrm{G}\right)$ & $m_{1}^{\prime}\left(\mathrm{at}_{\mathrm{o}}\right)$ & $m_{2}^{\prime}(\mathrm{at} \%)$ & $K\left(\mathrm{sec}{ }^{-1}\right)$ & $R_{1}^{\prime}(\mathrm{A})$ & $R_{2}^{\prime}(\mathrm{A})$ & $t_{m}(\mathrm{sec})$. & $D\left(\mathrm{~cm}^{2} / \mathrm{sec}.\right)$ \\
\hline 170 & 43.0 & 0.73 & $1.25 \times 10^{4}$ & 79.4 & 159.8 & 800 & $1.6 \times 10^{-15}$ \\
180 & 41.0 & 0.74 & $2.21 \times 10^{4}$ & 65.1 & 129.6 & 250 & $3.4 \times 10^{-15}$ \\
190 & 39.0 & 0.75 & $4.00 \times 10^{4}$ & 63.4 & 123.6 & 120 & $6.4 \times 10^{-15}$ \\
200 & 37.6 & 0.76 & $7.00 \times 10^{4}$ & 61.9 & 119.5 & 60 & $1.1 \times 10^{-14}$ \\
210 & 36.5 & 0.78 & $1.65 \times 10^{5}$ & 64.9 & 123.9 & 30 & $2.6 \times 10^{-14}$ \\
220 & 35.2 & 0.79 & $2.90 \times 10^{5}$ & 63.5 & 120.0 & 15 & $4.8 \times 10^{-14}$ \\
\hline
\end{tabular}

ここでまずみかけの活性化エネルギを求めてみる。

Fig. 10 は電気抵抗が極大に達するまでの時間の対数と $T_{R}$ の逆数の関係を示す。 $130^{\circ} \mathrm{C} て ゙ ~ 2$ 日間時効した合金に おいては単一の直線がえられ，その傾きからみかけの活 性化エネルギとして $32.4 \mathrm{kcal} / \mathrm{mol}$ がえられた。 $70^{\circ} \mathrm{C}$ で時効した合金の場合，160 $170^{\circ} \mathrm{C}$ を境として異なる 2 つのアーレニウスの関係が存在することが見出された。 これは時効および復元曲線から明らかにされたように， 160 $170^{\circ} \mathrm{C}$ を境としてG.P.ゾーンの状態が $\varepsilon$ から クに変 化することによると考えられる。高温部の直線の傾きか ら求めたみかけの活性化エネル ギは, $70^{\circ} \mathrm{C} に て 120$ 扰よ び22日時効した合金に対してそれぞれ 31.1 および 29.7 $\mathrm{kcal} / \mathrm{mol}$ であつた。一方, 耐力変化 (Fig. 2) からク口 ス・カット法で求めた場合の活性化エネルギは $32.6 \mathrm{kca} /$ mol であつた。このようにしてえられた復元のためのみ かけの活性化エネルギは $\mathrm{Al}-\mathrm{Ag}$ 合金中の $\mathrm{Ag}$ 拡散のため の活性化エネルギよりも $0.8 \sim 2.9 \mathrm{kcal} / \mathrm{mol}$ 大きい。

しかし，これらの結果は $\mathrm{Al}-\mathrm{Ag}$ 系に扔けるG.P.ゾーン の準安定状態図が Baur ら $^{2)}$ の提案したような形状であ るならば，復元温度による母相浱度の変化を考慮して補 正する必要がある。Gerold ら ${ }^{5}$ によれば Al-Ag合金にお いては $\mathrm{Ag}$ 濃度が $m_{1}$ で半径が $R_{1}$ の球状G.P.ゾーンが,

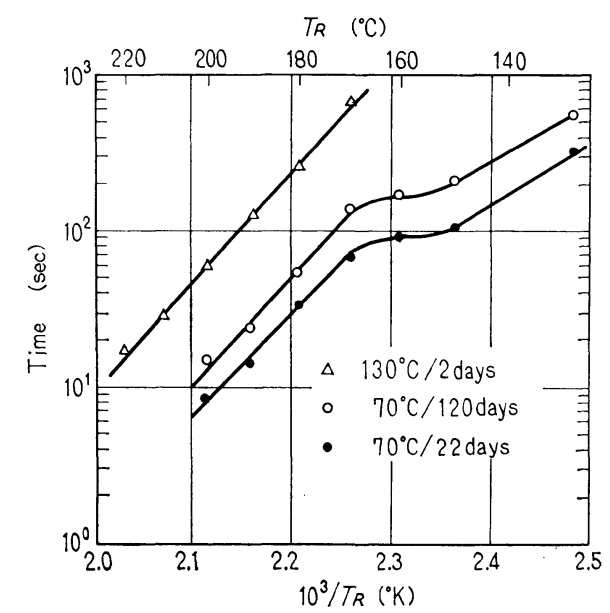

Fig. 10 Relation between $1 \operatorname{lnt}_{m}$ and $1 / T_{R}$, showing apparent activation energy of reversion.
$\mathrm{Ag}$ 濃度 $m_{2}$ で半径が $R_{2}$ の球殼状の母相に囲まれてい る。復元温度におけるこれらの值をそれぞれ $m_{1}^{\prime}, R^{\prime}{ }_{1}$, $m_{2}^{\prime}$ および $R_{2}^{\prime}$ とする。復元の前後において平均溶質濃 度は変化しないから次式が成立つ：

$$
\frac{m_{1}^{\prime} R_{1}^{\prime 3}+m_{2}^{\prime}\left(R_{2}^{\prime 3}-R_{1}^{\prime 3}\right)}{R_{2}^{\prime 3}}=m_{o}
$$

ただし, $\mathrm{Al}$ と $\mathrm{Ag}$ の原子半径の差を無視した。また $m_{0}$ は平均濃度であり, $\mathrm{Al}-20 \% \mathrm{Ag}$ 合金では $m_{o}=5.9$ (原子 パーセント) である。(4)式を変形すれば

$$
R_{2}^{\prime}=\left(\frac{m_{1}^{\prime}-m_{2}^{\prime}}{5.9-m_{2}^{\prime}}\right)^{1 / 3} \cdot R_{1}^{\prime}
$$

一方, Gerold ら²)によれば $R^{\prime}{ }_{1}$ は次式で与えられる：

$$
R_{1}^{\prime}=\left(\frac{m_{1}}{m_{1}^{\prime}}\right)^{1 / 3} \cdot R_{1}+\frac{K}{4 R_{1}^{3}} \cdot \Delta t
$$

ただし $K$ は G.P. ゾーン成長のための速度定数, $\Delta t$ は復 元処理時間であり, 今の場合 $t_{m}$ に等しいと仮定する。 (6)式を(5)式に代入すれば復元における $\mathrm{Ag}$ 原子の拡散距 離 $R_{2}^{\prime}$ が求まる。 $m_{1}, m^{\prime}, m_{2}, m^{\prime}{ }_{2}$ および $K$ の值は, Gerold ら5) の結果から内挿して求めた。 $\mathrm{Al}-20 \% \mathrm{Ag}$ 合 金を $130^{\circ} \mathrm{C}$ で 2 日間時効した場合， $R_{1}=42 \mathrm{~A}, m_{1}=55.0$ で あるので，これを用いて計算した結果を Table 1 に示 す。復元時の $\mathrm{Ag}$ の拡散係数は次式で求められる：

$$
\sqrt{2 D t_{m}}=R^{\prime}{ }_{2}
$$

これによつて求めたDは Table 1 の最後に示した。

Fig. 11 は $\ln D$ と $1 / T_{R}$ の関係を示す。これから求め た復元のための活性化エネルギは $29.0 \mathrm{kcal} / \mathrm{mol}$ であ り, $\mathrm{Al}-\mathrm{Ag}$ 合金中の $\mathrm{Ag}$ の拡散のそれと著しくよく一致 し, $\mathrm{Al}-\mathrm{Ag}$ 合金の復元が準安定状態図に従がう可能性が 強いことを暗示している。

一方, 復元が G.P. ゾーンの溶解過程である場合, Ag の拡散距離 $d$ は $R_{2}^{\prime}$ に無関係であるとすれば，(4)式に対 応して次式が成立つ：

$$
\frac{m_{1} R_{1}^{3}+m_{2}\left(d^{3}-R_{1}^{3}\right)}{d^{3}}=5.9
$$

前と同様, $R_{1}=42, m_{1}=55.0, m_{2}=0.54$ を代入すれば $d=91.2 A$ がえられる。したがっつて

$$
\sqrt{2 D^{\prime} t_{m}}=91.2
$$

(9)式によって求めた $D^{\prime}$ の值を Fig. 11 に示す。この場 合, $D^{\prime}$ は $t_{m}$ の逆数に比例するから $D^{\prime}$ の温度依存性か 


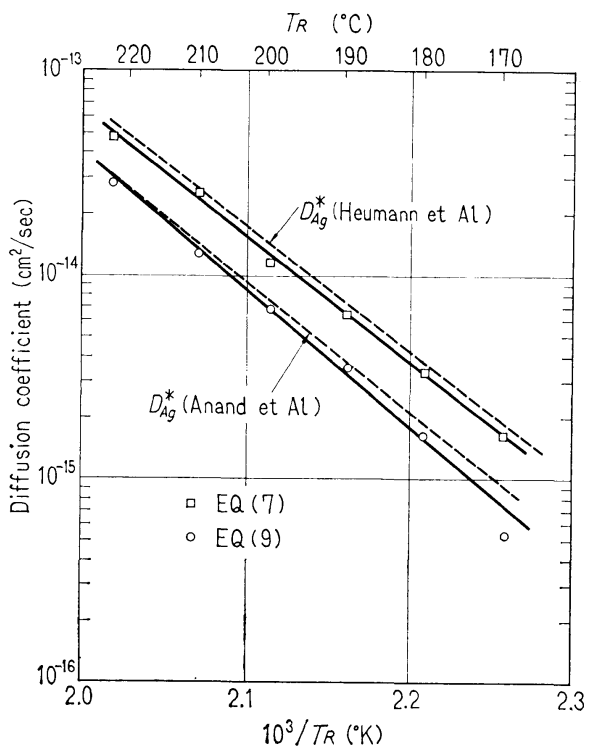

Fig. 11 Temperature dependence of diffusion coefficient of $\mathrm{Ag}$ in $\mathrm{Al}-\mathrm{Ag}$ alloy during reversion, showing true activation energy of reversion to be $29.0 \mathrm{kcal} / \mathrm{mol}$.

ら求めた活性化エネルギは $t_{m}$ の温度依存性 (Fig. 10) か ら求めた值 $(32.4 \mathrm{kcal} / \mathrm{mol})$ と変わらない。

Fig. 11 には Anand とAgarwala14) および Heumann と Böhmer ${ }^{13)}$ による $\mathrm{Al}$ または $\mathrm{Al}-\mathrm{Ag}$ 合金中の $\mathrm{Ag}$ の扡 散係数の外插值も示してある。(7)式から求めた $D$ は後者 と，(9)式から求めた $D^{\prime}$ は前者とほとんど完全に一致す る。したがつて, 復元過程の拡散の解析に関する限り, 復元が準安定状態図に従がつてゾーンの大きさ, 組成お よび母相濃度の変化によるのかまたはゾーンの固溶消隇 によるのかを断定することはできない。しかし，時効お よび復元に伴う耐力および電気抵抗変化が準安定状態図 に従がつていること，(9)式から求めた復元の活性化エネ ルギが $\mathrm{Al}-\mathrm{Ag}$ 合金中の $\mathrm{Ag}$ の拡散のそれよりも大きいこ となどから考えれば $\mathrm{Al}-20 \% \mathrm{Ag}$ 合金の復元が，Baur と Gerold ${ }^{2)}$ の準安定状態図に従がうと結論してもよいと 思われる。

\section{5. 結 論}

$70^{\circ} \mathrm{C}$ たは $130^{\circ} \mathrm{C} に て$ 種々の時間時効した $\mathrm{Al}-20 \% \mathrm{Ag}$ 合金の復元挙動を引張り試験および電気抵抗測定によっ て調べ，その機構を検討した。えられた結果は以下のと おりである。

(1) $130^{\circ} \mathrm{C}$ にて時効硬化した $\mathrm{Al}-20 \% \mathrm{Ag}$ 合金を $160^{\circ} \mathrm{C}$ 以 上に加熱すると耐力は減少するが，最大の耐力減少量は $170^{\circ} \mathrm{C}$ を境として顕著な相異を示す。これは復元がク一 $\varepsilon$ の変態によるとして解釈できる。

(2) $70^{\circ} \mathrm{C}$ たは $130^{\circ} \mathrm{C}$ で時効した $\mathrm{Al}-20 \% \mathrm{Ag}$ 合金の復元 に際して電気抵抗ははじめ増加し, 極大を経て減少す る。電気抵抗の最大増加量と復元温度の関係は耐力変化 の場合と同様であり， $170^{\circ} \mathrm{C}$ を境として $\varepsilon-\eta$ 変態が生 じると考えられる。

(3)電気抵抗の最大值に達するまでの時間は時効時間が 長いほど長い。これは復元時における拡散距離が時効時 間とともに増加することによる。

(4) $\mathrm{Al}-20 \% \mathrm{Ag}$ 合金の復元は準安定状態困に従がつた $\varepsilon$ 一ク変態過程であり， $\mathrm{Ag}$ 原子の払散によつて律速され る。復元に伴う母相濃度およびゾーンの大きさの変化を 考慮して求めた復元時の拡散係数から決定した活性化工 ネルギは $29.0 \mathrm{kcal} / \mathrm{mol}$ であり, $\mathrm{Al}-\mathrm{Ag}$ 合金中の $\mathrm{Ag}$ の拡 散のそれに等しい。

本研究の一部は軽金属奨学会助成金によつて行なつ た。記して感謝の意を表する。

\section{参考 文 献}

1) 広瀬，浅野，平野，軽金属，20(1970) 589

2) R. Baur and V. Gerold, Acta Met., 10 (1962) 637

3) W. Köster and F. Braumann, Z. Metallk., 43 (1952) 193

4) A. Guinier, Z. Metallk., 43 (1952) 217

5) R. Baur and V. Gerold, Z. Metallk., 52 (1961) 671

6) H. Auer and V. Gerold, Z. Metallk., 56 (1965) 240

7) K. Hirano, Trans. JIM, 10 (1969) 132

8) R. H. Beton and E. G. Rollason, J. Inst. Metals, 86 (1957-58) 85

9) A. Kelly and R. B. Nicholson, Progress in Materials Science, Vol. 10, Pergamon Press, 1961, p. 149

10) M. Ohta, Trans. JIM, 5 (1964) 174

11) H. Borchers and G. Thym. Z. Metallk., 60 (1969) 303

12）浅野, 平野, 日本金属学:会誌, 投稿中

13) Th. Heumann and H. Böhmer, J. Phys. Chem. Solids, 29 (1968) 237

14) M. S. Anand and R. P. Agarwala, Trans. AIME, 239 (1967) 1848 